\title{
Assessing the feasibility of establishing a centre of excellence in health logistics in the East African Community
}

\author{
Philippe Jaillard ${ }^{1 *}$, Lloyd Matowe ${ }^{2}$ \\ From The 2nd People that Deliver (2nd PtD) Global Conference on Human Resources in Supply Chain \\ Management \\ Copenhagen, Denmark. 29-30 October 2014
}

\section{Background}

The East African Community (EAC) seeks to address challenges of vaccine and other commodities supply chain management by addressing weaknesses in human resource capacity. To achieve this EAC seeks to establish a Center of Excellence $(\mathrm{CoE})$ with the objective of professionalizing health and immunization and related commodity logistics management in the region. The proposed framework for the CoE will be modelled according to the existing LOGIVAC reference center for health logistics for West African countries, in Benin. To advance this work AMP provided technical assistance to EAC to conduct a feasibility assessment.

\section{Method}

The assessment methodology was adapted from the Human Resources for Supply Chain Assessment Guide and Tool developed by USAID|DELIVER in conjunction with PtD, and the Competency Compendium for Health Supply Chain Management developed by PtD. Specifically, the approach used desk reviews, consensus workshops, key informant interviews and analyses of existing systems.

\section{Results}

In the East African Community, most SCM activities at the Central level are performed by pharmacists but nonpharmacists also play a significant role. At the facility level, SCM functions are mainly performed by nurses and midwives. In most countries EPI SCM functions are performed by public health technicians, clinical officers, nurses and midwifes. In all but one partner state there is

\footnotetext{
* Correspondence: pjaillard@aamp.org

${ }^{1}$ Agence de Médecine Préventive (AMP), Ferney-Voltaire, France

Full list of author information is available at the end of the article
}

at least one school of pharmacy. Even though pharmacists are being trained, current curricula for the pharmacy training does not adequately address SCM functions. In addition, curricula for nurses and midwives contains limited SCM. In all EAC Partner States, SC managers for EPI are mainly trained on the job.

\section{Discussion}

There are SCM training gaps in the EAC with most of the countries having inadequate numbers of pharmacists. Also, pharmacy assistants/technicians are in short supply across countries. In addition to insufficient numbers of SCM cadres, no course currently exists to train a specialized SC cadre. Institutions that provide courses in SCM exist but lack sufficient capacity to produce quality courses. In addition to the shortage of trained personnel, there are also insufficient numbers of $\mathrm{SC} /$ logistics management academics. Curriculum strengthening and academic capacity building initiatives are required to adequately address SCM HR challenges.

\section{Lessons learned}

A number of cadres, apart from pharmacists perform supply chain functions in the East African Community. Even though most EAC countries train pharmacists, these are in inadequate numbers and current curricula do not adequately prepare staff for SCM functions. Approaches to strengthen human recourse capacity for SCM are necessary to streamline SCM efficiency in the EAC.

\footnotetext{
Authors' details

${ }^{1}$ Agence de Médecine Préventive (AMP), Ferney-Voltaire, France.

${ }^{2}$ Pharmaceutical Systems Africa, Monrovia, Liberia.
}

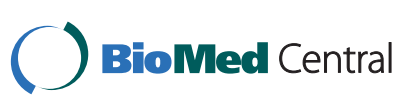

(c) 2014 Jaillard and Matowe; licensee BioMed Central Ltd. This is an Open Access article distributed under the terms of the Creative Commons Attribution License (http://creativecommons.org/licenses/by/4.0), which permits unrestricted use, distribution, and reproduction in any medium, provided the original work is properly cited. The Creative Commons Public Domain Dedication waiver (http://creativecommons.org/publicdomain/zero/1.0/) applies to the data made available in this article, unless otherwise stated. 
Submit your next manuscript to BioMed Central and take full advantage of:

- Convenient online submission

- Thorough peer review

- No space constraints or color figure charges

- Immediate publication on acceptance

- Inclusion in PubMed, CAS, Scopus and Google Scholar

- Research which is freely available for redistribution 